\title{
Corpo e linguagem em Nove noites, de Bernardo Carvalho, e "Meu tio o iauaretê", de João Guimarães Rosa
}

\author{
Body and language in Nove noites, by Bernardo Carvalho, and "Meu tio o \\ iauaretê", by João Guimarães Rosa
}

\section{Márcia Marques de Morais Rita Gabrielli}

Pontifícia Universidade Católica de Minas Gerais - PUC - Minas Gerais - Brasil

\begin{abstract}
Resumo: Este trabalho intenta refletir sobre a relação entre corpo e linguagem, a partir dos modos como ela é encenada em Nove noites, de Bernardo Carvalho, e "Meu tio o iauaretê", de Guimarães Rosa. No romance de Carvalho, narradores, agenciados pelo narrador-romancista, tentam esclarecer, a partir de múltiplos relatos, o suicídio de Buell Quain, que mutilou o próprio corpo, aniquilando-se, como resposta a um conflito entre seus desejos e o processo civilizatório que incide na existência de cada sujeito e a constitui. No conto de Rosa, por sua vez, o leitor depara com um narrador-escritor que, encenando o discurso oscilante do onceiro-jaguar, relata como o matou para salvar-se de ser devorado. Trata-se, portanto, de uma narrativa sobre a aniquilação de um corpo que, como último recurso à sobrevivência, volta-se para a natureza animalesca, diante da incidência da linguagem impossível de realizar-se satisfatoriamente na língua (dominadora) do outro. Como recursos a essa reflexão, são agenciadas a concepção de linguagem de Benveniste (1976a, 1976b,1989a, 1989b), a noção de ficção de Iser (2002) e a leitura do conto de Rosa feita por Wey (2005).
\end{abstract}

Palavras-chave: Linguagem. Corpo. Guimarães Rosa. Bernardo Carvalho. Literatura Comparada.

Abstract: This paper explores the relation between body and language as presented in Bernardo Carvalho's Nove noites, and in João Guimarães Rosa's "Meu tio o iauaretê". In Carvalho's novel, narrators, orchestrated by the narrator-novelist, try to clarify, from multiple reports, the suicide of Buell Quain, who mutilated his own body, annihilating himself in response to a conflict between his desires and the civilizing process that influences and constitutes the existence of each subject. In Rosa's short story, on the other hand, the reader comes across a narrator-writer who, staging the oscillating discourse of the jaguar, reports how he killed his interlocutor to save himself from being slain. The narrative is therefore about the annihilation of a body that, as a last resort to survival, turns to the animalistic nature, in the face of language's impossibility to perform satisfactorily before the (dominant) other's language. For this purpose, Émile Benveniste's conception of language, Wolfgang Iser's notion of fiction, and an essay about Guimarães Rosa's short story written by Valquiria Wey are used as reading resources

Key-words: Language. Body. Guimarães Rosa. Bernardo Carvalho. Comparative Literature. 
O propósito deste artigo é refletir sobre a relação entre corpo e linguagem, a partir dos modos como ela é encenada no romance Nove noites, de Bernardo Carvalho, e no conto "Meu tio o iauaretê", de Guimarães Rosa. Para tanto, é realizada uma leitura, num viés comparativo, entre o conto e o romance em questão, recorrendo-se à concepção de linguagem de Benveniste (1976a, 1976b, 1989a, 1989b), à noção de ficção de Iser (2002) e à leitura do conto de Rosa feita por Wey (2005).

O romance de Carvalho é uma narrativa em que um narrador-romancista, projetado pelo autor, ao ler o artigo de uma antropóloga sobre o suicídio de Buell Quain, ocorrido no Maranhão, em 2 de agosto de 1939, vê, no nome do etnólogo, intensa familiaridade, embora esse nome não lhe dissesse, aparentemente, nada. O narrador-romancista acaba encontrando explicação para essa inquietante sensação de familiaridade ${ }^{1}$ diante de um nome desconhecido: tratava-se de uma lembrança que the retorna de cena em que, num hospital, acompanhando seu pai, é chamado pelo nome "Buell Quain", por um senhor americano agonizante. Então, movido pelo enigma que esse nome passa a constituir para si, esse narrador investiga a vida e o suicídio de Buell Quain e acaba ficando "obcecado" pelas lacunas da história do antropólogo.

Diante da impossibilidade de preencher tais lacunas com dados factuais, mesmo se dedicando a cuidadosa e intensa investigação, o narradorromancista decide então preenchê-las com a sua imaginação, escrevendo um romance. Para tanto, cria um "testamento" cuja autoria ele atribui a Manoel Perna, que também atua como narrador no romance. Compõem ainda o relato metanarrativo do narradorromancista, além das cartas escritas pelo próprio Quain, epístolas trocadas entre vários personagens relacionados à vida do etnólogo americano.

Essas múltiplas vozes narrativas buscam esclarecer a morte do jovem pesquisador que mutilou o próprio corpo, aniquilando-se, como

\footnotetext{
1 Freud (1919/1976) foi o primeiro a exaustivamente falar em "estranho" e "familiar" quando se desdobra em analisar, do ponto de vista morfossemântico, o substantivo abstrato alemão Unheimliche.
}

resposta a um conflito entre seus desejos e o processo civilizatório que incide na existência de cada sujeito e a constitui. Contudo, essa busca pelo impossível não é vã. Por meio dela, denuncia-se a impossibilidade de se alcançar toda a verdade, todas as versões de um fato e, portanto, denuncia-se o caráter ficcional da própria realidade.

Assim, em Nove noites, por diversas vezes, é levantada a controvérsia do relato, que não dá conta de toda a experiência, mas é, ao mesmo tempo, a única forma de lidar com a impossibilidade de compreendê-la em sua totalidade. E é como uma forma de se haver com esse paradoxo que 0 narrador-romancista de Carvalho escreve seu romance. A esse respeito, destaca-se o trecho a seguir:

\begin{abstract}
Mas não me peça o que nunca me deram, o preto no branco, a hora certa. Terá que contar apenas com o imponderável e a precariedade do que agora lhe conto, assim como tive de contar com o relato dos índios e a incerteza das traduções do professor Pessoa. As histórias dependem antes de tudo da confiança de quem as ouve, e da capacidade de interpretá-las. E quando vier estará desconfiado. (CARVALHO, 2004, p. 8)
\end{abstract}

Nesse trecho, Manoel Perna - cujo discurso é construído por outro narrador, explicita a seu narratário, o fotógrafo amigo de Quain, o fato de que o discurso, que não só incide na experiência humana como também a constitui, é limitado, porque fornece apenas uma versão da realidade, o que significa trazer consigo certa medida de ficção. Toda vez que alguém fala ou escreve sobre um determinado fato, como Manoel Perna o faz sobre o suicídio do antropólogo, ele, necessariamente, faz uma seleção, já que não é possível dizer tudo. Não é possível, porque toda enunciação, para ser bem sucedida, deve respeitar limites determinados por convenções linguísticas e socioculturais. Não é possível dizer tudo também, porque a existência não cabe inteiramente na fala ou na escrita. Cada indivíduo, inevitavelmente, tem que se haver com o paradoxo de viver além do discurso, mas ter que se sujeitar a ele como condição à integração na sociedade.

Para prosseguir com a reflexão, de modo a torná-la clara, é necessário explicitar, ainda que 
sucintamente, as noções de linguagem, discurso e realidade que norteiam este trabalho. Segundo a perspectiva de Benveniste (1976a, 1976b,1989a, 1989b), a linguagem consiste numa capacidade constitutiva do homem e a língua, num sistema de signos que, quando posto em ação, caracteriza-se como possibilidade de realização da linguagem. A língua - essa sim, um instrumento - quando falada ou escrita é, então, discurso. Partindo dessa perspectiva, acrescida da relação de complementaridade entre ficção e realidade proposta por Iser (2002), pode-se dizer que é pela linguagem que o homem experiencia a realidade. A realidade, por sua vez, justamente por ser nomeada e, portanto, vivenciada através de sistemas de signos, é constrangida aos limites da linguagem, que impõem à realidade a condição de seleção; como foi dito, não se pode dizer tudo e, portanto, não se pode acessar a realidade em sua totalidade. Se a realidade é construída/vivenciada a partir de processos de seleção, ela é, então, constituída por ficções. Além de a realidade estar atrelada à ficção pelo fato de estar sujeita ao discurso, que lhe impõe uma seleção, ela o está também pelo fato de que a própria matéria do discurso, a língua, possui uma dimensão ficcional. Ora, as coisas não são, efetivamente, os nomes que as designam, mas o homem somente as vivencia atribuindo-lhes nomes, significando-as, narrando-as. Mas, se nem tudo pode ser significado, e o homem precisa significar 0 mundo, ele está fadado a ter que lidar com os limites que o discurso impõe à sua necessidade incessante de significação. Como uma das formas de lidar com esse impasse, o homem recorre à literatura, que é, por excelência, transgressora dos limites do signo, (re)significando-os.

Quando Manoel Perna explicita, naquele trecho transcrito anteriormente, a sua impossibilidade, bem como a de seu interlocutor, e a do próprio Bernardo Carvalho e dos leitores empíricos, de acessar toda a verdade ("o preto no branco", "a hora certa") sobre o suicídio de Buell Quain, ele está, justamente, tratando desse impasse humano. Há sempre uma parcela inacessível da experiência de cada sujeito com a qual, diante da impossibilidade de compreendê-la, só é possível lidar pela "precariedade do relato" e "contando(-se)" com o "imponderável". E porque o relato é limitado, conforme discutido, ele depende da "confiança de quem [o] ouve" e da "capacidade de interpretação", para atender seu propósito de auxiliar os sujeitos a lidarem com o incompreensível da existência. O que Perna evidencia, então, é o caráter ficcional do relato, seja ele literário ou não, e da própria realidade, já que ela é constituída por narrativas. A diferença entre as narrativas "reais" - como as construídas por textos legislativos (discurso da lei) ou científicos (discurso da ciência), por exemplo, - e as narrativas "ficcionais" - como as literárias -, conforme propõe Iser (2002), estaria, então, em que essas últimas operam, na realidade, a partir do "desnudamento" de sua ficcionalidade.

O pensador da estética da recepção diferencia o caráter ficcional de uma obra literária do de outros textos considerados não-ficcionais, destacando o fato de que esses últimos, por possuírem função reguladora, precisam ser tomados como detentores de verdades inquestionáveis, apesar de serem, também, construídos pela ficção do signo. Um texto literário, ao contrário, opera pelo desnudamento de sua ficcionalidade, porque precisa de que o mundo ali encenado seja tomado como uma possibilidade de realidade, mas que a excede. Isso porque a literatura tem função transgressora e é, justamente por mostrar-se diferente da realidade, que ela pode promover mudanças e (re)significar o que não pode ser mudado, como, por exemplo, a impossibilidade de significar plenamente a existência. Um escritor, ao selecionar e relacionar traços da realidade, do "mundo vivencial", combinando-os com a sua imaginação, cria, pela via do signo, uma nova realidade, a do "mundo do texto", em que cabe, mais do que a realidade como ela é, a realidade como ela deveria ser (ou, pelo menos, como o autor acredita que ela deveria ser, ou gostaria de que ela fosse). Dessa forma, o leitor tem acesso a uma outra versão da realidade, diferente da que ele conhece, e é 
convidado a também operar mudanças no seu mundo vivencial e a (re)significar os seus limites.

Ainda a respeito do caráter ficcional da realidade, é crucial para o romance de Bernardo Carvalho o termo "miragens" utilizado por Manoel Perna, ao tentar compreender o que levou Quain a suicidar-se. Ele (o narrador) afirma: "É preciso entender que cada um verá coisas que ninguém mais poderá ver. $E$ que nelas residem as suas razões. Cada um verá as suas miragens." (CARVALHO, 2004, p. 48). Como foi dito, há sempre uma parcela da experiência de cada sujeito que extrapola o discurso, embora o sujeito tenha que limitar-se a ele, como parte do pacto social. Essa parte além-discurso da existência do indivíduo, ainda que não possa ser compartilhada - e por isso mesmo é incompreensível aos outros e, em parte, ao próprio indivíduo - o movimenta na realidade. Dito de outro modo, as "miragens" singulares, que extrapolam a realidade, concomitantemente, constituem a vivência real do sujeito e determinam a sua forma de estar no mundo; as "miragens" de um sujeito constituem "as suas razões". Mas, diante do que se falou até o momento, como exatamente se relacionam linguagem e corpo?

Em determinada passagem do relato das nove noites que consistiram na sua breve, porém intensa, convivência com o antropólogo, Manoel Perna reflete sobre o suicídio do amigo, enxergando, nesse ato, uma resposta singular a uma experiência comum à condição humana. Ele diz assim:

Em algum momento, todos se sentirão sozinhos e abandonados. Só um teste incessante aos limites do corpo pode nos dar a consciência de que continuamos vivos. Se pomos o corpo à prova, não é pelo capricho fútil de saber até onde podemos ir, não é para desafiar os limites, mas para saber onde estamos - embora aos outros possa parecer que cometemos um ato contra a natureza. $\mathrm{E}$ muitas vezes, quando descobrimos, já é tarde. (CARVALHO, 2004, p. 132-133).

Se o sujeito é atravessado por "miragens", ficcionais, pois extrapolam discurso e realidade, ao mesmo tempo em que tem sua vivência real constituída por elas, parece natural que esse sujeito se sinta, por vezes, "sozinho" e "abandonado". Em outras palavras, se há uma parte da existência do indivíduo sobre a qual ele não pode falar, a respeito da qual ele não pode indagar o outro, para compreendê-la, é possível que ele se sinta, em determinados momentos, um tanto fora da experiência comum, da realidade, e, em última instância, da própria vida. Ele precisará, então, de algo que o situe no mundo, quando o discurso não parece capaz de fazê-lo. O corpo talvez possa ser tomado como o símbolo irrefutável da existência, que, de tanto ser testado, pode levar à morte, como prova última de que se estava vivo, de que se estava "aqui" e "agora". O suicídio, como encenado em Nove noites, e, sobretudo, de acordo com o que se aborda nesse trecho especificamente, parece poder ser tomado como testemunho extremo da insuficiência da linguagem.

Conforme foi dito, na paráfrase realizada no princípio deste artigo, o nome "Buell Quain" passa a constituir enigma para o narrador-romancista de Bernardo Carvalho, no momento em que o narrador depara com o nome do antropólogo em um artigo de jornal e incomoda-se, profundamente, com a inexplicável familiaridade diante do nome. É, nesse momento, também, que Ihe retorna a lembrança do episódio em que acredita ter ouvido o nome "Buell Quain” pela primeira vez: o narrador-escritor estava acompanhando o pai no hospital, quando um senhor americano, pouco antes de falecer, chama-o de "Buell Quain". Esse nome, portanto, constitui para o escritor ficcional de Carvalho um enigma duplo: "quem foi Buell Quain?" e "por que razão fui eu a presenciar a morte daquele 'velho' que me chamou de 'Buell Quain'?". Transcreve-se, a seguir, o trecho em que o escritor de Carvalho fala sobre o momento em que se lembrou do episódio em que foi confundido com o dono do enigmático nome:

No dia seguinte [depois da morte do americano] eu já não pensava mais no velho ou no que me disse na sua agonia. Era o dia da minha partida. Minha vida seguiu o seu rumo. Meu pai morreu três meses depois. Fiquei três anos fora. Já faz nove anos que voltei para São Paulo. Mas foi só ao ler o artigo da antropóloga há oito meses, e ao repetir em voz alta aquele nome que eu não conhecia e ainda assim me parecia familiar: "Buell Quain, Buell Quain", que de repente me 
lembrei de onde o tinha ouvido antes $e$, fazendo a devida correção ortográfica na minha cabeca, descobri de quem falava 0 velho americano no hospital, quem era a pessoa a que ele se referia e que havia esperado por tanto tempo. (CARVALHO, 2004, p. 146-147, grifo nosso)

A investigação do narrador-romancista, engendrada a partir do encontro com o nome no artigo e com a lembrança das circunstâncias em que presenciou a morte de alguém pela primeira vez, pode ser lida como uma tentativa de encontrar uma forma de compreender a forte identificação que ele experiencia diante do jovem antropólogo. A escrita do romance, que nasce da impossibilidade de preencher as lacunas da história do antropólogo e também do próprio narrador-romancista, é possível de ser lida como uma resposta à inexplicabilidade subjacente àquela identificação.

Buscar pela história do sujeito cujo nome aparece no artigo de jornal é, afinal, buscar pela própria história no ponto em que ela se une à do outro (a de Buell Quain), como forma de lidar com aquela identificação enigmática, causada pela palavra de outrem. Escrever o romance é, então, escrever, registrar, dar consistência à inexplicabilidade tanto do desfecho da existência de Buell Quain, quanto do episódio em que um estranho liga a história do antropólogo ao narrador, ao atribuirIhe os significantes (Buell Quain) que nomearam a existência do jovem etnólogo. Foram contingenciais as experiências de (re)encontrar o nome do etnólogo no artigo de jornal, de presenciar a morte do senhor americano enquanto estava perdendo o pai para uma doença implacável e de ser chamado pelo nome do etnólogo. Foi contingencial, também, a identificação com Buell Quain. No entanto, essas contingências foram determinantes para a história do narrador-romancista. Determinante para cada sujeito é, também, a consciência da inevitabilidade da morte. A forma como o narrador-romancista lida com os efeitos dessas experiências, e mesmo com a morte, é distinta da forma como o Buell Quain de Carvalho lida com o processo civilizatório constituinte das subjetividades.
Houve um antropólogo, aluno da Universidade de Columbia, chamado Buell Quain, que, enquanto estava a trabalho no Brasil, decidiu cortar-se e enforcar-se, aniquilando-se, sem oferecer explicação. Trata-se, portanto, de um evento que tem sua significação limitada pela ausência da palavra. Não há quem possa explicar o suicídio do antropólogo e, por isso, os significados que esse ato possa ter estarão sempre sujeitados à inexistência de signos que o expliquem. $O$ encontro do narradorromancista com o nome de Buell Quain, naquele artigo, por sua vez, revela-se enigmático pela exuberância da palavra. É um nome familiar, mas desconhecido, que pode significar qualquer coisa e, justamente por isso, acaba não significando nada; mas, ainda assim - e talvez até em função disso -, produz efeito sobre o corpo, incomoda. É um nome que demanda significação e, para tanto, é necessário que seja circunscrito a um evento familiar ao sujeito. O limite revelado, a partir do encontro tanto com a falta quanto com o excesso da palavra, que tanto incomoda, é necessário à significação e, portanto, indispensável aos sujeitos. O efeito da incidência desse limite na vida de cada indivíduo pode ser tanto paralisante - como ocorreu com o Quain de Bernardo Carvalho, que precisou extrapolar o limite do corpo destruindo-se, quanto motivador como o foi para o narrador-romancista, que criou uma narrativa, sob a forma de um romance, a partir dessa experiência. O que parece determinar o teor criativo ou destrutivo - da forma como o indivíduo lida com esse limite é a sua capacidade de atribuir sentido(s) ao encontro com ele.

Em "Meu tio o iauaretê", a relação entre corpo e linguagem é encenada de forma a também apontar a morte e o relato como respostas possíveis ao encontro com o limite do discurso. Só que a morte é abordada, dessa vez, pela via do assassinato, e o relato é feito sob a forma de um conto. O narradorencenado, o onceiro-jaguar de nome perdido e identidade ambígua, é assassinado a revólver pelo narrador-contista, que o faz para impedir o outro de devorá-lo. O narrador-contista relata tal episódio, encenando o discurso do mestiço (de mãe índia e pai 
branco), que é contratado por um fazendeiro para matar onças e acaba regressando a sua familiaridade com elas, passando a matar humanos. O conto, que tem a forma de um diálogo virtual ${ }^{2}$, já que o interlocutor é pressuposto apenas pela sinalização de sua presença na organização discursiva do locutor, é construído a partir da criação de uma língua híbrida, que faz que o leitor experimente 0 estranhamento diante da impossibilidade de compreender completamente o que fala o iauaretê. Nessa língua artificial, de significados enigmáticos, conforme aponta Wey (2005), escondem-se as duas atitudes básicas do onceiro-jaguar diante do visitante, a saber, a hostilidade em função de ter seu território descoberto e invadido e a fascinação pelos objetos portados pelo outro. Sobre as configurações dessa língua e a sua função de ambiguizar as emoções e intenções do homem-jaguar, Wey explicita o seguinte:

\begin{abstract}
Sempre que pode Guimarães funde raízes brasileiras com o tupi, criando uma forma ambivalente, e, quando é necessário, aproveita da brevidade das partículas do tupi, dos metaplasmos, da nasalização e dos sons guturais, para esconder no texto manifestações emotivas em formas interjetivas e onamatopéicas, criando uma espécie de relato particular do narrador, fazendo assim que o leitor demore em entender a verdadeira natureza licantrópica do mestiço, e, mais importante, mostra, na concretização duma língua própria do iauaretê, o seu irreversível isolamento cultural e social. Guimarães Rosa constrói uma língua para não ser compreendida na totalidade de seus significados. (WEY, 2005, p. 350)
\end{abstract}

Na perspectiva da professora da Universidad Nacional Autónoma de México, a criação da língua do iauaretê por parte de Rosa revela o posicionamento do autor sobre a questão da ocidentalização da cultura indígena e da (im)possibilidade de sua sobrevivência pela via da mestiçagem. Nas palavras de Valquiria Wey:

\footnotetext{
2 Essa forma de diálogo virtual, denominada por Antonio Candido (1970) como "operação de alta estética" e por Davi Arrigucci Jr. (1994) como "esquema técnico", é encontrada também em Grande Sertão: Veredas (apud Morais, 2006). Embora "Meu tio o iauaretê" tenha sido o primeiro texto em que Rosa experimentou esse recurso, o conto só foi publicado postumamente, em Estas estórias, conforme, também, atesta Davi Arrigucci Jr. (1994).
}

\begin{abstract}
A tese de Rosa, proposta na construção do concreto da linguagem do iauaratê, da dupla linguagem, da língua oculta, representando o mundo esquizofrênico de culturas que não se absorvem, parece negar a possibilidade do trânsito cultural, da migração de uma cultura para a outra. A mestiçagem, que foi transformada pelo latinoamericanismo positivista numa categoria para pensar a integração da cultura indígena e a colonial, é esmiuçada neste conto do Rosa para mostrar a impossibilidade da permeação entre universos assimétricos, colocando em evidência a idealização do mestiço e o barroquismo, em termos de tensão de opostos, da sua existência. (WEY, 2005, p. 353)
\end{abstract}

Os estudos literários têm demostrado, ao longo de sua história, que uma obra literária apresenta múltiplas possibilidades de leitura. Ainda referentemente a esse fato, o diálogo dos estudos literários com os estudos linguísticos enfatiza que as atividades de leitura e escrita consistem em processos enunciativos dos quais participam sujeitos constituídos por experiências singulares, que negociam significados/sentidos, a partir de suas maneiras próprias de vivenciar o processo civilizatório. Assim, nota-se que "Meu tio o iauaretê", além de abordar, como Wey evidencia, a impossibilidade de uma relação pacífica e integrada entre a cultura indígena e a colonial, trata, também, da relação entre linguagem e corpo. E esse tratamento é feito pela encenação da renúncia de um indivíduo ao pacto social, como resposta à impossibilidade de sustentar sua subjetividade na língua do outro. A língua híbrida com a qual se constrói o discurso oscilante do onceiro-jaguar revela um sujeito que tenta esconder sua identificação com a natureza pré-linguística, animalesca, justamente para realizá-la, devorando o seu interlocutor. Enquanto a parcela tupi da língua do iauaretê lhe serve para expressar a ira, sem que o outro a perceba, a parte portuguesa, que corresponde à língua do seu interlocutor, é usada, ao mesmo tempo, para agenciar a simpatia do outro e para amedrontá-lo. É como se, com essa estratégia discursiva, o mestiço visasse à iminência do sucesso: "ou eu o venço ganhando a sua confiança, ou eu o derroto aguçando o seu medo". Exemplo disso é o trecho a seguir: 
Cê pode comer tudo, 'manhã eu caço mais, mato veado. 'Manhã, mato veado não: carece não. Onça já pegou cavalo de mecê, pulou nele, sangrou na veia-altéia... Bicho grande já morreu mesmo, e ela inda não larga, tá em riba dele... Quebrou cabeça do cavalo, rasgou pescoço... Quebrou? Quebroou!... Chupou o sangue todo, comeu um pedação de carne. Depois, carregou cavalo morto, puxou pra a beira do mato, puxou na boca. Tapou com folhas. Agora ela tá dormindo, no mato fechado... Pintada começa comendo a bunda, a anca. Suaçurana começa p'la 'pá, p'los peitos. Anta, elas duas principeiam p'la barriga: couro é grosso... Mecê 'creditou? Mas suaçurana mata anta não, não é capaz. Pinima mata; pinima é meu parente!... (ROSA, 1976, p. 127-128)

Insinua-se, nesse trecho, o comportamento ambíguo do homem-jaguar, oscilante entre anfitrião atencioso, ofertando comida em fartura, e cruel predador, que não só possui a ferocidade da onça, como também a crueldade humana de quem se delicia com a aflição que o relato minucioso do "modus operandi" desse animal pode causar. O iauaretê, primeiro, apresenta sua face amigável, oferecendo comida à vontade ao visitante; depois, afirma que a onça fez do cavalo do visitante alimento e, então, descreve o modo como esse predador ataca. Aparece aí a sua face voraz. Ele se identifica com a onça ("Pinima mata; pinima é meu parente"), indiciando que o cavalo, posse do interlocutor - e, portanto, a ele relacionado - metaforiza-o. Como se não bastasse, para atingir o efeito desejado, o homem-jaguar ainda sublinha a sua ferocidade, quando afirma que o jaguar, que é seu "parente", seu igual, é mais "capaz" e potente que outro predador, a "suaçurana". Ele faz isso, depois de enunciar uma pergunta ("Mecê 'creditou?") que parece ser destinada à averiguação dos efeitos do seu discurso sobre o interlocutor, à averiguação do quanto de sua intenção fatal se revelou.

Logo em seguida, como se o corpo deixasse escapar a intenção predatória que o discurso vacilante se esforça para ocultar, o homem-jaguar ri, depois de voltar a afirmar sua familiaridade com a onça: "Agora, eu já sei: onça é que caça pra mim, quando ela pode. Onça é meu parente. Meus parentes, meus parentes, ai, ai, ai... Tou rindo de mecê não. Tou munhamunhando sozinho pra mim, anhum." (ROSA, 1976, p. 128) O domínio do discurso se revela, então, crucial para que o iauaretê consiga realizar seu objetivo. O visitante é astuto, possui maior domínio discursivo que o mestiço e um revólver como meio de matar, se preciso for. É necessário, então, que o mestiço o convença a se desarmar. Só a sua força física não vai bastar. Por essa razão é que começa uma luta linguageira entre o homem-jaguar e seu interlocutor. Este trabalha para fazer o mestiço falar, por meio de instigantes perguntas e pela oferta de cachaça. $\mathrm{O}$ iauaretê, por sua vez, se esforça por convencer o visitante a dormir:

Mecê tá com febre. Devia deitar no jirau, rebuçar com a capa, cobrir com couro, dormir. Quer? Cê tira a roupa, bota relógio dentro do casco de tatú, bota o revólver também, ninguém bole. Eu vou bulir em seus trens não [...] Mecê não quer dormir? Tá bom, tá bom, não falei nada, não falei...(ROSA, 1976, p. 131)

São muitas as tentativas do mestiço de vulnerabilizar seu interlocutor, que se defende, fazendo-o falar - talvez para distraí-lo de sua intenção - e ofertando-Ihe cachaça, provavelmente, na esperança de fazê-lo incapaz de realizar um ataque bem sucedido. Tal estratégia do interlocutor se revela frutífera: "Nhem? Camarada traz outro garrafão? Mecê me dá? Hã-hã... Ããã... Apê! Mecê quer saber? Eu falo. Mecê bom-bonito, meu amigo meu." (ROSA, 1976, p. 142) E, quanto mais o iauaretê falha em persuadir o outro a adormecer, mais agressivo ele se torna, tendo como único recurso mostrar-se mais forte e poderoso que seu interlocutor:

Por que é que não deita? - fica só acordado me preguntando coisas, depois eu respondo, depois cê pregunta outra vez outras coisas? Pra que? Daí, eh, eu bebo sua cachaça toda. Hum, hum, fico bêbado não. Fico bêbado só quando eu bebo muito, muito sangue... Cê pode dormir sossegado, eu tomo conta, sei ter olho em tudo. Tou vendo, cê tá com sono. Ói, se eu quero eu risco dois redondos no chão pra ser seus olhos de mecê - despois piso em riba, cê dorme de repente... Ei, mas mecê também é corajoso capaz de encarar homem. Mecê tem olho forte. Podia até caçar onça... Fica quieto. Mecê é meu amigo. (ROSA, 1976, p. 140) 
Nesse excerto, o iauaretê sugere que a sua vontade não depende da palavra para realizar-se e, tampouco, a cachaça o aliena de seu desejo. Quando ele afirma que somente o sangue o embriaga, ele intenta convencer o visitante de que ele (o iauaretê) é imune à sua "alquimia" (do visitante). $\mathrm{E}$, ao alertar o interlocutor do fato de que pode obrigá-lo a dormir por meio de feitiço, o homem-jaguar está insinuando sua suposta imunidade às leis do signo. Mas, em seguida, quando o interlocutor parece reagir recorrendo ao revólver (já que o mestiço pede: "Fica quieto. Mecê é meu amigo"), o homem-jaguar se vê obrigado a reconhecer a força do visitante ("Ei, mas mecê também é corajoso capaz de encarar homem. Mecê tem olho forte. Podia até caçar onça...").

Pela necessidade de recuar, diante da demonstração de poder do visitante, que responde às ameaças do mestiço, mostrando, pelo revólver, que sua vontade também pode desvincular-se da palavra, o iauaretê volta a usar sua face amigável para desarmar o outro. Exemplo disso é o trecho a seguir:

Ei, quem sabe revólver seu tá panema, hã? Deixa eu ver. Se tiver panema, eu dou jeito... Ah, cê não quer não? Cê deixa eu pegar em revólver seu não? Mecê já fechou os olhos três vezes, já abriu a boca, abriu a boca. Se eu contar mais, cê dorme será? (ROSA, 1976, p. 142-143).

Depois de narrar o episódio em que, transformado em onça, matou o Preto Tiodoro, chega o momento, enfim, em que o mestiço não é mais capaz de conter-se e, consequentemente, encontra o limite último da existência, a morte:

Mecê gostou, ã? Preto prestava não, ô, ô, ô... Ói: mecê presta, cê é meu amigo... Ói: deixa eu ver mecê direito, deix'eu pegar um tiquinho em mecê, tiquinho só, encostar minha mão... Ei, ei, que é que mecê tá fazendo?

Desvira esse revólver! Mecê brinca não, vira o revólver pra outra banda... Mexo não, tou quieto, quieto... Ói: cê quer me matar, ui? Tira, tira revólver pra lá! Mecê tá doente, mecê tá variando... Veio me prender? Ói: tou pondo mão no chão é por nada, não, é à-toa... Ói o frio... Mecê tá dôido?! Atiê! Sai pra fora, rancho é meu, xô! Atimbora! Mecê me mata, camarada vem, manda prender mecê... Onça vem, Maria-Maria, come mecê... Onça meu parente... Ei, por causa do prêto? Matei preto não, tava contando bobagem... Ói a onça! Ui, ui, mecê é bom, faz isso comigo não, me mata não... Eu - Macuncozo... Faz isso não, faz não... Nhenhenhém... Heeé!...

Hé... Aar-rrâ... Aaâh... Cê me arrhoôu... Remuaci... Rêiucàanacê... Araaã... Uhm... Ui... Ui... Uh... uh... êeêê... êê... ê... ê... (ROSA, 1974, p. 158-159)

O homem-jaguar falhou em se valer da linguagem para realizar seu desejo de devorar o outro. Ele não foi capaz de persuadir o visitante a não usar o revólver; não foi capaz de distraí-lo, enganá-lo, para tornar possível o seu ataque; por isso, não foi páreo para o desejo do outro de matálo. Quando, já encurralado na/pela mira do revólver, reconhece a impossibilidade de viver fora das regras impostas pela cultura, representada pelo visitante (com sua argúcia linguageira acrescida de potência "bélica"), intenta voltar atrás na sua escolha de recusá-la. O iauaretê, como último recurso à sobrevivência, à preservação do corpo, tenta instaurar-se como sujeito pertencente à cultura do visitante, enunciando "eu - Macuncozo... Faz isso não, faz não..." - o que equivale a dizer: "eu me sujeitarei às suas regras; não me mate"

A morte do homem-jaguar se caracteriza, portanto, como o resultado da incidência da linguagem sobre o corpo, impossível de realizar-se, satisfatoriamente, na língua do outro. Nessa sociedade, trazida metonimicamente pelo visitante e representada, também, no plano extratextual pelo autor e pelos leitores, só é possível existir, satisfatoriamente, se se sabe falar, se o sujeito detém o saber de usar a língua para negociar a realização de seus desejos com o outro. O corpo sedento de sangue humano era o único símbolo da existência do iauaretê, que nem de nome mais dispunha. Na medida em que o domínio da cultura colonial foi afastando-o de suas origens, o mestiço foi mudando de nome, de identidade, até que o isolamento total, imposto pela impossibilidade de adaptar-se criativamente às expectativas do outro, deixou-o sem um signo que sustentasse a sua subjetividade. A esse respeito, destaca-se o trecho a seguir: 
Nome meu minha mãe pôs: Bacuriquirepa. Breó, Beró, também. Pai meu me levou para o missionário. Batizou, batizou. Nome de Tonico; bonito, será? Antonho de Eiesus... Depois me chamavam de Macuncozo, nome era de um sítio que era de outro dono, é - um sítio que chamam de Macuncozo... Agora, tenho nome nenhum, não careço. Nhô Nhuão Guede me chamava de Tonho Tigreiro. Nhô Nhuão Guede me trouxe pr'aqui, eu nhum, sozim. Não devia! Agora tenho nome mais não... (ROSA, 1976, p. 144)

Numa primeira fase de sua vida, conforme se vê no excerto acima, o homem-jaguar tinha dois nomes indígenas, escolhidos pela mãe. Esses, posteriormente, quando o mestiço se afastou do seio indígena por intermédio do pai, foram substituídos por um nome cristão, "Antonho de Eiesus". O nome cristão deu lugar, então, ao nome do sítio "de outro dono" (Macuncozo), lugar em que, provavelmente, o iauaretê trabalhou sob condições de exploração. Nesse período, o homem-jaguar foi nomeado pela função social (desprivilegiada) que exercia; tinha o nome da propriedade do outro, o que sugere 0 apagamento de sua condição de sujeito. Depois, ao ser contratado para "desonçar" o sertão, pelo Nhô Nhuão Guede, passou a ser conhecido pelo seu nome cristão, associado à sua habilidade singular de caçar onças, e então, passa a chamar-se Tonho Tigreiro.

Durante o tempo em que foi Tonho Tigreiro, o mestiço atuou conforme as expectativas da cultura ocidental e exerceu, assim, sua subjetividade. Tonho tinha uma habilidade singular e a usou como forma de trabalho; recebia pagamento e moradia, exercendo, assim, uma função como membro da sociedade:

Nhô Nhuão Guede me trouxe pra cá. Me pagava. Eu ganhava o couro, ganhava dinheiro por onça que eu matava. Dinheiro bom: glim-glim... Só eu é que sabia caçar onça. Por isso Nhô Nhuão Guede me mandou ficar aqui, mor de desonçar este mundo todo. (ROSA, 1974, p. 128-129)

Quando se percebeu, porém, contrariando a própria natureza, em nome do reconhecimento de uma cultura que o marginalizava, ele escolheu renunciar ao pacto social, identificando-se com a onça, comportando-se como ela e, assim, tornandose predador do homem. Ao fazer isso, rompeu o pacto civilizatório e pôs-se num "entre-lugar": passou a ser nem-todo sujeito, nem-todo animal. Como consequência dessa escolha, encontrou, primeiro, a solidão - uma forma de semi-existir ("eu nhum, sozim"/ eu nenhum, sozinho / sujeito nenhum, sozinho) - e, por fim, a morte - a completude da inexistência.

Perder o nome equivale a perder o signo que sustenta a existência numa determinada cultura. A inexistência de um nome próprio para designar o onceiro-jaguar simboliza a inexistência dele como membro da sociedade; simboliza a sua desvinculação com a civilização. O visitante, que, no plano simbólico, funciona como uma espécie de metonímia do limite da existência do iauaretê - já que evidencia o indizível da experiência do onceiro acaba tornando-se o limite real da existência do mestiço, ao aniquilar seu corpo, ao assassiná-lo. Assim, a língua artificial de Rosa, construída, "para não ser compreendida na totalidade de seus significados" (WEY, 2005, p. 350), metaforiza não só a impossibilidade do "trânsito cultural" pelo "irreversível isolamento cultural e social" do iauaretê, como, também, a inevitável impossibilidade da compreensão de todos os significados que o encontro com a ausência ou o excesso da palavra pode adquirir na vida de um sujeito. A incompreensibilidade da língua criada por Guimarães Rosa, denuncia, portanto, a incompreensibilidade inerente à linguagem, que é, concomitantemente, constitutiva da realidade e aquém da vivência real dos sujeitos, por ser esta sempre marcada pelas "miragens" singulares e indizíveis.

Quanto ao assassino do onceiro-jaguar, ao ter que recorrer ao revólver para não ser devorado, encontrou também o limite da palavra. Por mais que o iauaretê narrasse sua experiência, a linguagem já não era suficiente para que ele sustentasse a sua subjetividade dentro das normas da sociedade desvinculada da cultura indígena. $O$ narradorcontista, então, (re)significa esse episódio em que a palavra não bastou, narrando-o, por meio da encenação do discurso do onceiro-jaguar, fazendo-o enunciar - como se, pela literatura, pudesse atender 
o último (e irrealizável) pedido do iauaretê, que foi de (re)existir. E ele faz o iauaretê (re)existir, mostrando que o seu próprio discurso, a sua própria identidade, é, desde o trágico embate, marcada pela do seu rival. Outro indício de que, desde aquele fatal (des)encontro, instaurou-se, para o narrador-contista, certa familiaridade com o rival assassinado é apresentado no título do conto. "Meu tio o iauaretê": essa frase que nomeia a narrativa explicita a relação de parentesco, de semelhança entre os rivais, através dos significantes "meu tio". Trata-se, portanto, de uma forma de expressão da qual se vale o narrador para reconhecer a familiaridade entre ele e o mestiço.

Tanto o romance de Bernardo Carvalho, quanto o conto de Guimarães Rosa evidenciam a relação constitutiva entre corpo e linguagem, trazendo em si sujeitos ficcionais que lidam com a incidência da linguagem no corpo de maneiras distintas e mesmo opostas. O Buell Quain de Carvalho e o iauaretê acabam por abdicar da potência criadora da linguagem, que, apesar de impor limites ao sujeito - e até mesmo por isso -, possibilita a coexistência das ficções singulares e da realidade. Diante de conflitos entre as "miragens" singulares e as ficções sancionadas como realidade, próprios da dinâmica social, o antropólogo e o mestiço se enredaram no indizível de suas experiências, concebendo o corpo como único recurso possível para atestar o real de suas existências. No excesso do corpo, encontram a prova última de que existiam: puseram o corpo à prova; pereceram. Em Nove noites, o leitor não encontra indícios mais específicos das motivações que levaram Quain a suicidar-se; encontra somente (e não poderia ser diferente), muitas e infundadas especulações levantadas pelas vozes narrativas. 0 que o leitor pode afirmar é que, para esse sujeito, algo, na sua forma de vivenciar a dinâmica social, o processo civilizatório, deu errado, de forma a levá-lo a aniquilar-se. Já, em "Meu tio o iauaretê", é explicitada uma particularidade referente à dificuldade do personagem em adaptar-se satisfatoriamente à sociedade: para que o mestiço fosse bem sucedido na manutenção do pacto social, ele teria que se afastar radicalmente de sua origem indígena, cuja cultura é irremediavelmente incompatível com a cultura colonial. Não foi possível, para o mestiço, abdicar de hábitos, crenças, valores, nem realizar sua capacidade de linguagem na língua do outro, do colonizador, fazendo dela a sua própria língua. A sua resposta diante dos conflitos provenientes do hiato entre o que ele queria para si e o que a sociedade poderia oferecer-lhe foi resistir, violentamente, na defesa de seus desejos, devorando, aniquilando o outro. Como consequência da sua recusa em lidar criativamente com os limites impostos pelo processo civilizatório, o iauretê foi assassinado.

Quanto aos escritores ficcionais das obras, o narrador-romancista de Carvalho e o narradorcontista de Rosa, ambos recorreram à apropriação artística da linguagem como forma de tratar do indizível da experiência de cada um. Como "esforço de formalização de impasses" (IANNINI, 2013), o escritor ficcional de Nove noites criou um romance narrado por múltiplas vozes, em que ensaia explicações para as lacunas da história de Quain e do ponto da sua própria história que se liga à do antropólogo, justamente para evidenciar a impossibilidade de compreendê-las. Resulta, também, desse trabalho de tratamento do impossível pela via da escrita, a evidenciação do caráter ficcional da realidade, da existência de "miragens" singulares que determinam as experiências de cada um dos sujeitos e do fato de que essas ficções singulares aproximam e afastam, concomitantemente, todos os sujeitos (PEREIRA, 2014). Elas os aproximam, porque todos experienciam uma existência constituída por ficções incompreensíveis e indispensáveis, e os afastam, porque impossibilitam que um sujeito entenda completamente o outro, que um sujeito se identifique inteiramente com o outro. Em outras palavras, como resultado do seu exercício em lidar com o que da sua experiência escapa à linguagem, o narradorromancista evidencia o fato de que o que faz todos 
os sujeitos familiares uns aos outros é também o que os faz estranhos.

De outro modo, o narrador-contista de Rosa escreve um conto, encenando o discurso do iauaretê, como forma de lidar com a experiência de ter assassinado alguém, quando a palavra não bastou. Assim, ele evidencia o mesmo que o escritor de Carvalho: apesar de tudo o que fazia do iauaretê estranho a ele e seu rival, o escritor ficcional de Rosa reconhece sua semelhança com o mestiço no ponto em que, diante da insuficiência da linguagem, ambos recorreram à violência como forma de defesa de seus modos de estarem no mundo. Entretanto, o escritor de Rosa não abdicou da linguagem. Ainda que ele tenha precisado matar o mestiço, ele permanece inscrito nos limites da linguagem, no pacto social, e vale-se da escrita literária para refletir sobre a experiência do assassinato. $\mathrm{Na}$ /pela escrita do conto, o narrador-contista reconhece a brutalidade do seu ato, que extinguiu a vida de um "parente", de um semelhante. Encenar o discurso do iauaretê é, para o narrador-contista, uma forma de conceder ao iauaretê a satisfação de seu último e (irrealizável) desejo: o de existir.

Assim, recorrendo-se, pela via da recepção, à força performativa (no sentido que Iser atribui ao termo) da literatura, bem como à sua característica sem-igual de fazer balançar os limites do signo, pretendeu-se evidenciar (e principiar uma reflexão sobre) a relação entre corpo e linguagem. Vale dizer, por fim, que o caráter intrincado dessa relação requer, evidentemente, um estudo mais aprofundado e extenso. Este artigo, portanto, consiste num primeiro ensaio para a realização de uma reflexão mais minuciosa, a partir da literatura, sobre a relação entre corpo e linguagem.

\section{Referências}

ARRIGUCCI JR., Davi. O mundo misturado: romance e experiência em Guimarães Rosa. In: Novos Estudos/CEBRAP (40). São Paulo: novembro de 1994, p. 7-29.

BENVENISTE, Émile. A natureza dos pronomes. In: BENVENISTE, Émile. Problemas de linguística geral. Tradução de Maria da Glória Novak e Maria Luiza Neri. São Paulo: Companhia Editora
Nacional e Editora da Universidade de São Paulo. 1976a. p. 277-283.

BENVENISTE, Émile. Da subjetividade na linguagem. In: BENVENISTE, Émile. Problemas de linguística geral. Tradução de Maria da Glória Novak e Maria Luiza Neri. São Paulo: Companhia Editora Nacional e Editora da Universidade de São Paulo. 1976b. p. 284-293.

BENVENISTE, Émile. A linguagem e a experiência humana. In: BENVENISTE, Émile. Problemas de linguística geral II. Tradução de Eduardo Guimarães et al. Campinas: Pontes. 1989a. p. 6880.

BENVENISTE, Émile. O aparelho formal da enunciação. In: BENVENISTE, Émile.

Problemas de linguística geral II. Tradução de Eduardo Guimarães et al. Campinas: Pontes. 1989b. p. 81-90.

CANDIDO, Antônio. Jagunços mineiros: de Cláudio a Guimarães Rosa. In: Vários escritos. São Paulo: Duas Cidades, 1970. p. 135-160.

CARVALHO, Bernardo. Nove noites. 2. ed. São Paulo: Companhia das Letras, 2004. 170 p.

FREUD, Sigmund. O "estranho" (1919). In: História de uma neurose infantil e outros trabalhos (1918 [1914]). Tradução de Eudoro Augusto Macieira de Souza. Rio de Janeiro: Imago, 1976, p.19-151.

IANNINI, Gilson. Estilo e verdade em Jacques Lacan. 2. ed. Belo Horizonte: Autêntica Editora, 2013. $374 \mathrm{p}$.

ISER, Wolfgang. Os atos de fingir ou o que é fictício no texto ficcional. In: COSTA LIMA, Luiz (Org.). Teoria da literatura em suas fontes. 3. ed. Rio de Janeiro: Civilização Brasileira, 2002. v.2. p. 955987.

MORAIS, Márcia Marques. O romance se fez letra a metaliteratura em Grande Sertão: Veredas. O eixo e a roda, Belo Horizonte, v. 12, p. 202-214, 2006. Disponível em: < http://www.periodicos.letras.ufmg.br/index.php/o eixo_ea_roda>. Acesso em: 26 nov. 2016.

PEREIRA, Rita Gabrielli. Ruínas no discurso, discurso em ruínas e o trabalho de Sísifo: considerações sobre categorias da crítica literária, a partir de "Dois irmãos", de M. Hatoum, e "eles eram muitos cavalos", de L. Ruffato. 2014. 88 f. Dissertação (Mestrado em Letras Literaturas de Língua Portuguesa) - Programa de Pós-Graduação em Letras, Pontifícia Universidade Católica de Minas Gerais, Belo Horizonte, 2014. Disponível em: $<\mathrm{http}$ ://www.biblioteca.pucminas.br/teses/Letras_ PereiraRG.pdf>. Acesso em: 09 dez. 2016. 
ROSA, João Guimarães. Meu tio o iauaretê. In: ROSA, João Guimarães. Estas estórias. 2. ed. Rio de Janeiro: José Olympio, 1976. p. 126-159.

WEY, Valquiria. Entrar para a tribu literária: a tradução de "Meu tio o iauaretê". Scripta, Belo Horizonte, v.9, n.17, p. 340-355, 2ํsem. 2005.

\section{COMO CITAR ESSE ARTIGO}

DE MORAIS, Márcia Marques; GABRIELLI, Rita. Corpo e linguagem em Nove noites, de Bernardo Carvalho, e "Meu tio o iauaretê", de João Guimarães Rosa. Signo, Santa Cruz do Sul, v. 42, n. 74, maio 2017. ISSN 19822014. Disponível em: <https://online.unisc.br/seer/index.php/signo/article/view/8712>. Acesso em: doi: http://dx.doi.org/10.17058/signo.v42i74.8712. 